\title{
Excellent response of infantile orbital hemangioma to propranolol
}

\section{Fandresena A Sendrasoa Irina M Ranaivo Naina H Razanakoto Malalaniaina Andrianarison Lala S Ramarozatovo F Rapelanoro Rabenja \\ Department of Dermatology, University Hospital Joseph Raseta Befelatanana, Antananarivo, Madagascar}

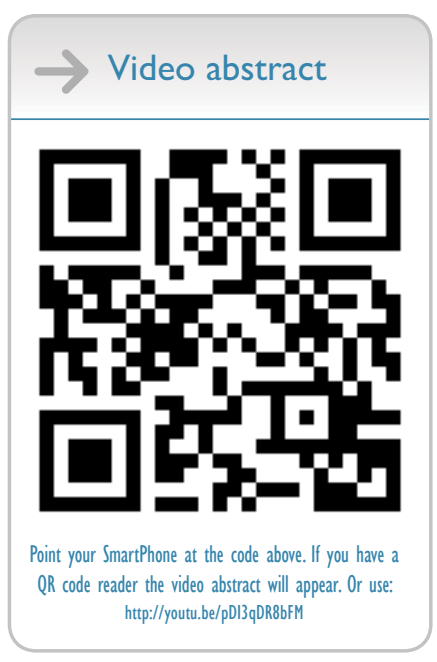

Correspondence: Fandresena A Sendrasoa

Department of Dermatology, University Hospital Joseph Raseta Befelatanana, Rue Dr Davioud Jacques, Antananarivo I0I, Madagascar

Tel +26I 330 47I 344

Email nasendrefa@yahoo.fr
This article was published in the following Dove Press journal:

International Medical Case Reports Journal

17 November 2016

Number of times this article has been viewed

\begin{abstract}
Infantile hemangiomas are the most common vascular neoplasm that present in infancy, with more than half affecting the head and neck region. Periocularly, hemangiomas may be complicated by visual loss through induction of strabismal, deprivational, or anisometropic astigmatism. We report a case of a 5-year-old girl who presented with orbital hemangioma with potential risk of visual loss who had excellent response to propranolol.
\end{abstract}

Keywords: hemangioma, orbital, propranolol

\section{Introduction}

Infantile hemangiomas are common, benign vascular tumors of infancy. They are commonly located on the face. ${ }^{1}$ When occurring periocularly and left untreated, their visual sequelae are common. ${ }^{2}$ In 2008, Léauté-Labrèze et al reported the effect of propranolol in infantile hemangiomas, which provoked a paradigm shift in its management. ${ }^{3}$ Propranolol has since been increasingly adopted as a first-line treatment for infantile hemangiomas. ${ }^{4}$ We present a 5 -year-old girl with orbital hemangioma associated with potential risk of visual loss who had excellent response to propranolol.

\section{Case report}

A 5-year-old girl, otherwise healthy, presented with a swelling over the right infraorbital region of 6 months' duration. Written informed consent was obtained from the parent for the publication of this case report and the photographs. The mass was slowly increasing in size, but did not cause any pain. There was no history of trauma or prematurity. However, advanced maternal age (44 years) was identified. Clinical examination revealed a swelling with dimensions of $2 \times 1.5 \mathrm{~cm}$, which appeared bluish and protruded from beneath the skin. The mass was firm, untender, and mobile (Figure 1). The surrounding skin was normal. She also presented upward deviation of the right eye. On ocular examination, her visual acuity was $4 / 10$ in the right eye and $10 / 10$ in the left. On right fundus examination, venous tortuosity and dilation in the central retinal vein were found. B-mode ultrasound showed a partially cystic mass in close proximity to the medial rectus. Cranial and orbital magnetic resonance imaging showed a $T_{1}$-hypointense, $T_{2}$-hyperintense $15 \times 12 \mathrm{~mm}$ lesion, serpiginous in axial shorttime inversion recovery, involving adipose tissue and the right medial rectus muscle, which caused slight displacement of the optic nerve (Figure 2). The anterior wall of the right orbit was thickened, and the right maxillary sinus was involved. However, 
there was no bone defect. Blood investigations were normal. Oral propranolol was planned after explaining risks and benefits to the parents and pretreatment evaluation. It was initiated at $2 \mathrm{mg} / \mathrm{kg}$ body-weight/day as a single oral dose. It was well tolerated by the patient, with hourly monitoring of heart rate, respiratory rate, and blood pressure showing no abnormalities. No side effects were noted. The child was followed up for the first month on a 2-weekly basis, then onward at monthly intervals. Significant response was noted at 2 months with paleness of the lesion. At 11-month follow-up, there was complete disappearance of the orbital hemangioma (Figure 3), and her visual acuity of the right eye reached 9/10. Furthermore, fundus abnormalities disappeared. Gradual tapering and stoppage of propranolol is planned over the next month with continued monthly surveillance. To date, we have observed no recurrence following propranolol discontinuation, with a follow-up of 6 months.

\section{Discussion}

Infantile hemangiomas are common childhood vascular tumors, occurring in 1\%-3\% of newborns, more frequently in



Figure I Swelling over the right infraorbital region. premature infants, and in $10 \%$ of children by 1 year of age. ${ }^{5}$ Infantile hemangiomas usually appear on the face. A third of all eyelid and orbital hemangiomas are diagnosed at the time of birth, and almost all are identified by 6 months of age. ${ }^{6}$ In the periocular region, these lesions may cause functional and cosmetic deformities. ${ }^{7}$ Haik et $\mathrm{al}^{8}$ analyzed the clinical records of 101 patients with hemangiomas of the orbit and eyelids. The main signs noted were a subcutaneous or anterior orbital fullness and a periocular swelling with superficial strawberry hemangioma. Proptosis and ocular displacement were common findings among all patient groups. Children with hemangiomas of the orbit and eyelids often present ocular complications, such as amblyopia, optic neuropathy, keratopathy, and strabismus. The incidence of ocular complications ranges from $53 \%$ to $80 \% ;^{8}$ these high rates of ocular complications support the relevance of early treatment.

A large, multicenter prospective study examining the demographics of infantile hemangiomas found female sex, Caucasian ethnicity, prematurity, low birth weight, multiple gestations, and advanced maternal age to be risk factors. ${ }^{9}$ Advanced maternal age was identified in the current case.

Most hemangiomas can be diagnosed on clinical examination, and do not require any investigation. However, imaging is needed in cases of deep hemangioma or in cases of clinically atypical soft-tissue masses. Ultrasonography and magnetic resonance imaging are the commonly used modalities of choice.

The present case is unusual, due to the onset of signs after age 4 years. For most infants with infantile hemangioma, involution begins between 6 and 12 months of age. Although the process continues over years, the majority of
A

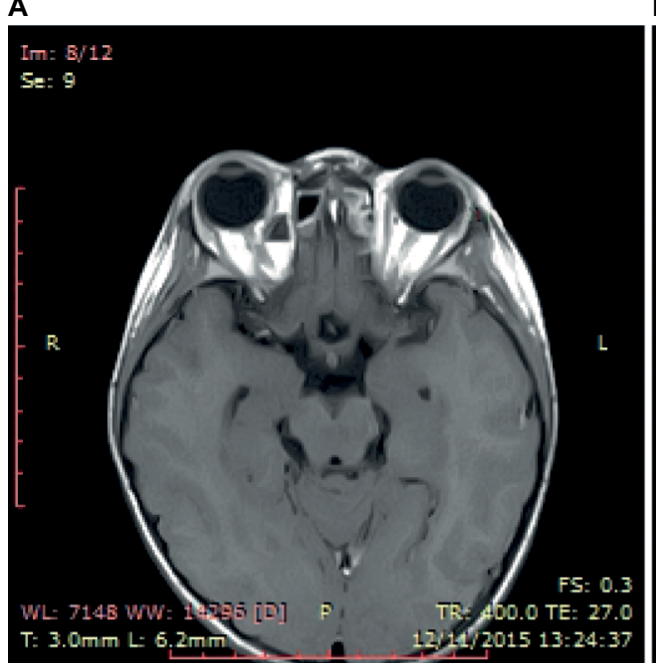

B

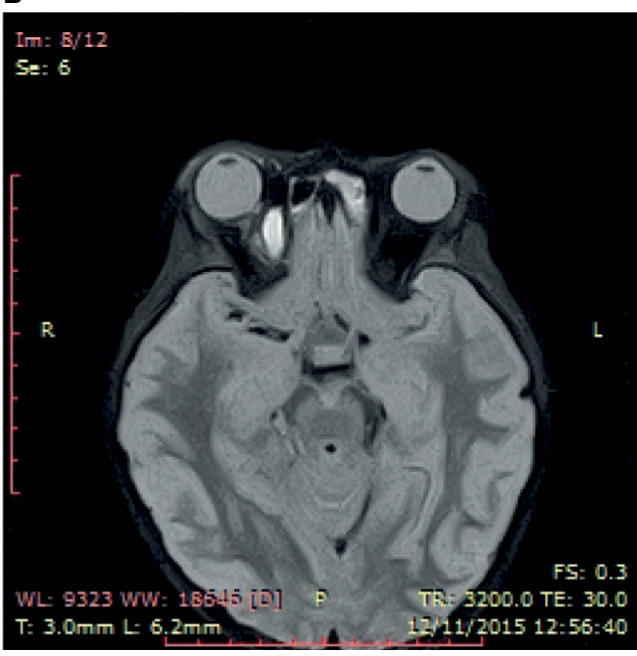

Figure 2 Magnetic resonance imaging showing (A) $T_{1}$-hypointense, (B) $T_{2}$-hyperintense $15 \times 12 \mathrm{~mm}$ lesion, involving adipose tissue and the right medial rectus muscle. 


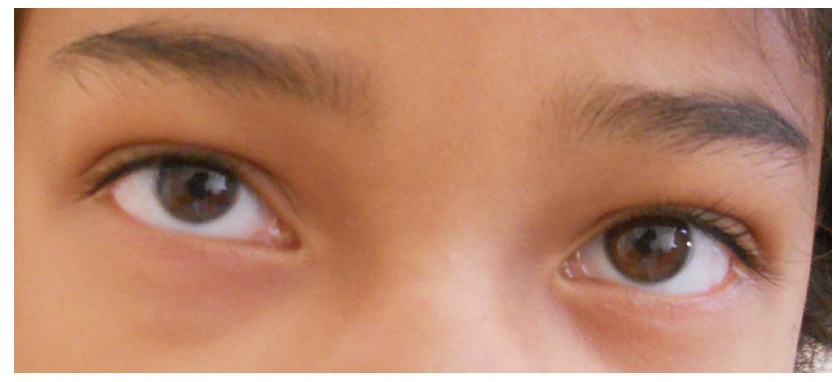

Figure 3 Complete disappearance of the orbital hemangioma (I Ith-month).

tumor regression occurs before age 4 years. Although most infantile hemangiomas resolve spontaneously, some may warrant medical or surgical treatment, because of interference with function or life-threatening physiologic compromise.

Various pharmacological agents, such as systemic or intralesional steroids, interferon, vincristine, bleomycin, cyclophosphamide, or imiquimod, have been used in the treatment of infantile hemangioma, with no single uniformly safe and effective treatment. ${ }^{10}$ Furthermore, laser treatment, embolization, or surgery may be effective for superficial hemangiomas, but remains problematic and harmful for deep or extensive forms, such as intraorbital hemangiomas. The impressive effect of propranolol in treating infantile hemangiomas has provoked a paradigm shift in their management since 2008. ${ }^{3,11}$ In addition, good tolerance of propranolol has been established. ${ }^{12}$ Treatment with propranolol has become the mainstay of systemic therapy for periocular lesions. Numerous case series suggest success not only in controlling the growth and size of the lesion but also in improvement of astigmatism. ${ }^{13,14}$

\section{Conclusion}

This patient's case illustrates the effectiveness and safeness of propranolol in treating complex infantile hemangiomas.
Close monitoring of the infants is required, considering the risk of side effects or relapse.

\section{Disclosure}

The authors report no conflicts of interest in this work.

\section{References}

1. Lo K, Mihm M, Fay A. Current theories on the pathogenesis of infantile hemangioma. Semin Ophtalmol. 2009;24(3):172-177.

2. Wahrman J, Honig P. Haemangiomas. Paediatric Rev. 1994;15(7): 266-271.

3. Léauté-Labrèze C, de la Roque ED, Hubiche T, et al. Propranolol for severe hemangiomas of infancy. NEnglJMed. 2008;358(24):2649-2651.

4. Drolet BA, Frommelt PC, Chamlin SL, at al. Initiation and use of propranolol for infantile hemangioma: report of a consensus conference. Pediatrics. 2013;131(1):128-140.

5. Shields CL, Shields JA, Minzter R, Singh AD. Cutaneous capillary hemangiomas of the eyelid, scalp, and digits in premature triplets. Am J Ophthalmol. 2000;129(4):528-531.

6. Haik BG, Karcioglu ZA, Gordon RA, Pechous BP. Capillary hemangioma (infantile periocular hemangioma). Surv Ophthalmol. 1994;38(5): 399-426.

7. Coats DK, O’Neil JW, D’Elia VJ, Brady-McCreery KM, Paysse EA. SubTenon's infusion of steroids for treatment of orbital hemangiomas. Ophthalmology. 2003;110(6):1255-1259.

8. Haik BG, Jakobiec FA, Ellsworth RM, Jones IS. Capillary hemangioma of the lids and orbit: an analysis of the clinical features and therapeutic results in 101 cases. Ophthalmology. 1979;86(5):760-792.

9. Haggstrom AN, Drolet BA, Baselga E, Chamlin SL, Garzon MC. Prospective study of infantile hemangiomas: demographic, prenatal, and perinatal characteristics. J Pediatr. 2007;150(3):291-294.

10. Nguyen J, Fay A. Pharmacologic therapy for periocular infantile hemangiomas: a review of the literature. Semin Ophthalmol. 2009;24(3):178-184.

11. Burne R, Taylor R. Monitoring propranolol treatment in periocular infantile haemangioma. Eye (Lond). 2014;28(11):1281-1285.

12. Thoumazet F, Léauté-Labrèze C, Colin J, Mortemousque B. Efficacy of systemic propranolol for severe infantile haemangioma of the orbit and eyelid: a case study of eight patients. Br J Ophthalmol. 2012;96(3): 370-374.

13. Ni N, Guo S, Langer P. Current concepts in the management of periocular infantile (capillary) hemangioma. Curr Opin Ophthalmol. 2011;22(5): 419-425.

14. Al Dhaybi R, Superstein R, Milet A, et al. Treatment of periocular infantile hemangiomas with propranolol: case series of 18 children. Ophthalmology. 2011;118(6):1184-1188.
International Medical Case Reports Journal

\section{Publish your work in this journal}

The International Medical Case Reports Journal is an international, peer-reviewed open-access journal publishing original case reports from all medical specialties. Previously unpublished medical posters are also accepted relating to any area of clinical or preclinical science. Submissions should not normally exceed 2,000 words or

\section{Dovepress}

4 published pages including figures, diagrams and references. The manuscript management system is completely online and includes a very quick and fair peer-review system, which is all easy to use. Visit http://www.dovepress.com/testimonials.php to read real quotes from published authors. 